\title{
PIENINIŲ DANTŲ KOMPLIKUOTO ĖDUONIES GYDYMO METODAI
}

\author{
Vitalija Siurblytė, Eglè Aida Bendoraitienė, Eglẻ Slabšinskienė, Rūta Grigalauskienė, \\ Ingrida Vasiliauskienè, Jaunẻ Razmienè \\ Lietuvos sveikatos moksly universitetas, Burnos priežiüros ir vaiku odontologijos klinika
}

Raktažodžiai: pieninių dantų anatomija, pulpotomija, pulpektomija, formokrezolis, pulpos terapija.

\begin{abstract}
Santrauka
Pieninių dantų èduonis yra viena dažniausių vaikų lètinių ligų, ir tai yra globali problema, ypač neišsivysčiusiose ir besivystančiose šalyse, kur vyrauja žemas pragyvenimo lygis bei prasta socioekonominè padètis. Odontologinès infekcijos, atsirandančios laiku negydant èduonies pažeistų dantų, daro neigiamą įtaką bendrai vaiko sveikatai, sukelia mitybos problemas, stresą gydant dantis, ugdymo ịstaigų nelankymą, vaikai drovisi bendrauti ir žaisti, o ilgainiui negydytas ėduonis sukelia dar daugiau ịvairių komplikacijų dantų skausmą, minkštụjų audinių tinimą, odontogeninị sepsị, nemigą, valgymo sutrikimus, mažą kūno masès indeksą $[2,27]$. Pieninių dantų komplikuoto èduonies gydymo galimybės yra aktuali tema, nes šalyse, kuriose yra didelis èduonies paplitimas, vaiku pieninių dantų èduonis dažniausiai yra negydomas. Šiame straipsnyje aptariami konservatyvūs ir radikalūs pieninių dantų komplikuoto èduonies gydymo metodai, jiems naudojamos medžiagos.
\end{abstract}

\section{Ivadas}

Pasaulinès sveikatos organizacijos duomenimis, pieninių dantų ėduonis yra viena dažniausių vaikų ligų, jos paplitimas kai kuriose šalyse siekia $90 \%$ [1, 26]. Lietuvos 4-6 metų vaikų pieninių dantų ėduonies paplitimas ir intensyvumas yra 89,7 proc. [2], o 50 proc. trimečių turi ertmini dantų èduoni [3].

Pirmas ir svarbiausias žingsnis gydant pieninių dantų pulpos patologijas - nustatyti tikslią diagnozę, remiantis ligos anamneze, klinikiniais bei radiologiniais duomenimis, nes tai padeda pasirinkti tinkamą gydymo būdą [4]. Konservatyvių eduonies gydymo metodų tikslas yra išsaugoti pieninių dantų lankų ir dantis supančių struktūrų vientisumą, pieninių dantų pulpos gyvybingumą, sumažinti atliekamų pulpektomijų skaičių, išvengti chirurginio ankstyvo pieninių dantų pašalinimo $[5,6]$. Tačiau konservatyvius metodus galima taikyti tik tiems pieniniams dantims, kurie neturi jokiu pulpos dirginimo simptomų ar degeneracijos požymių [4]. Jeigu nėra galimybių atlikti konservatyvaus pieninių dantų gydymo, galima taikyti pulpektomiją - pašalinti visą vainikinę ir šakninę pulpą, siekiant išsaugoti pieninị dantị dantų lanke. Tačiau tai sudètingesnis gydymo būdas, ypač mažamečiams vaikams. Kai èduonis komplikuojasi vietiniu patinimu, fistule, patologine šaknų ar vidine rezorbcija, periapikaliniu židiniu arba abscesu, tuomet indikuotinas radikalus pieninių dantų gydymas - šalinimas [6].

Tai yra bendros pieninių dantų pulpos patologiju gydymo rekomendacijos, kurios skirtingų šalių klinikinejje praktikoje taikomos atsižvelgiant ị kiekvienos šalies èduonies paplitimo, intensyvumo rodiklius bei socioekonominę padèti, esamas gydymo galimybes. Mažiau išsivysčiusiose arba besivystančiose šalyse dauguma ėduonies atvejų yra negydyti ir komplikuoti, èduonis pažeidžia mažo ir labai mažo amžiaus vaikus, todèl atsiranda gydymo bendrinejje narkozejje poreikis.

Gydant vaikus bendrinèje narkozėje, dažniausiai jiems taikomi pieninių dantų gydymo metodai - ertmių plombavimas ir dantų pašalinimas [27]. Per anksti pašalinus pieninius dantis, padideja ortodontinių deformacijų rizika - atsiranda papildomo ortodontinio gydymo poreikis. Taip pat pastebèta, kad praejjus 6 mènesiams po bendrinès narkozès, dauguma vaikų turi naujų èduonies pažeidimų ir nepakankamą burnos higieną - kyla pakartotinio gydymo bendrinèje narkozèje poreikis [27]. Taip vaikai patiria dar daugiau streso, naudojami dideli finansiniai ištekliai pieninių dantų gydymui. Taip pat tyrimais įrodyta, kad vaikų, kurių pieniniai dantys buvo pažeisti èduonies, nuolatiniuose dantyse ėduonis vystosi tris kartus dažniau. [28] Racionaliausia išeitis - ėduonies pažeidimų profilaktika ir ankstyvas ėduonies pažeidimų gydymas, kai dar galima pritaikyti konservatyvius pulpos patologijų gydymo metodus.

Darbo tikslas: išanalizuoti mokslinèje literatūroje aprašomus pieninių dantų komplikuoto ėduonies gydymo metodus, aptarti jiems naudojamas medžiagas. 


\section{Tyrimo objektas ir metodai}

Straipsnių, susijusių su šios literatūros apžvalgos tema, paieška vyko PMC ir PubMed duomenų bazèse, naudojant šiuos raktinius paieškos žodžius: primary teeth anatomy, pulpotomy, pulpectomy, formocresol, pulp therapy. Atrinkti straipsniai anglu kalba ir ne senesni nei 10 metų, siekiant aktualios ir naujos informacijos apie pieninių dantų komplikuoto eduonies gydymo metodus ir rekomendacijas. Tačiau ịtraukti ir keli senesni šaltiniai, kuriuose esanti informacija fundamentali.

Pieninių dantų anatomijos ypatumai. Pieninių ir nuolatinių dantų morfologija skirtinga. Nuo vidinès pieninių dantų anatomijos priklauso tai, jog dantu èduonis labai greitai komplikuojasi pulpos pažeidimu. Pieniniu dantų emalio sluoksnis yra plonesnis ir puresnis, todèl pieniniai dantys baltesni nei nuolatiniai, tačiau tuo pačiu mažiau atsparūs rūgščiu poveikiui. Emalio prizmès yra mažesnès, tai lemia prastesni kristalizuotos struktūros išsidèstymą. Chemine pieninių dantų emalio struktūra taip pat šiek tiek skiriasi nuo nuolatinių. Jame yra randami didesni kiekiai karbonato priemaišų, kurie padidina emalio tirpumą, taip pat nustatomas fosfatų trūkumas bei randami tokie elementai kaip stroncio ir cinko pédsakai, kurie manoma didina emalio jautrumą èduoniui $[7,8]$.

Pieninių dantų pulpos kameros santykinai yra didesnès, todèl pulpos ragai išsidėstę aukščiau. Pulpos kraujagyslès ir nervai yra didesni, apsupti puriu jungiamuoju audiniu [4], dažnos horizontalios anostomozès bei papildomi kanalèliai furkacijose [9]. Šaknų kanalų sistemos yra labai sudètingos dèl susijungiančių smulkių kanalèlių šakų bei papildomų didelių lateralinių kanalų. Dèl to šaknų kanalų sistemos gali turèti ịvairiausias variacijas, ypač pieninių krūminių dantų apikaliniuose trečdaliuose [10]. Dèl pieninių dantų pulpos uždegimo dažnai ir greitai pažeidžiamas kaulas furkacijos srityje, nes šioje srityje yra daug papildomų kanalèlių, bei pieniniai krūminiai dantys turi daugiau viršūnių nei nuolatiniai [10].

Pieninių dantų anatomijos žinojimas yra būtinas diagnozuojant ir priimant gydymo sprendimus. Būtina atkreipti dèmesị $i$ tai, kad pieniniuose dantyse mineralizuotas sluoksnis tarp išorinių ir vidinių danties struktūrų yra plonesnis ir tai lemia greitas pulpos patologijas.

Pieninių dantų pulpos gydymo būdai. Pieninių dantų pulpos gydymo metodai gali būti suskirstyti ị dvi grupes: konservatyvūs (kurių tikslas išsaugoti pulpos gyvybingumą) bei radikalūs (kai pašalinama ir vainikinè, ir šakninè pulpa arba pašalinamas dantis). Nors pulpotomija yra vainikinès pulpos pašalinimas, tačiau šis metodas taip pat priskiriamas konservatyviems gydymo metodams, nes šakninè pulpa išsaugoma gyva.

Konservatyvūs pieninių dantų pulpos gydymo būdai.
1. Tiesioginis pulpos padengimas. Tai metodas, kurio metu atsivèręs (dèl traumos, valant gilų èduonį) danties pulpos ragelis padengiamas bioaktyvia medžiaga, dažniausiai kalcio hidroksidu, ir dantis atstatomas hermetiška restauracija [11]. Tiesioginio pulpos padengimo metodas taikomas tik tuo atveju, jei dantis iki tol buvo besimptomis, pulpos atverimas yra labai minimalus ir užtikrinama visiška seilių izoliacija [4]. Tačiau net ir idealiomis sąlygomis atliktas pieninių dantų tiesioginis pulpos padengimas neefektyvus - stebimas mažas sèkmès procentas [4, 11]. Manoma, jog taip yra dèl gausaus nediferencijuotų mezenchiminių ląstelių kiekio pieninių dantų pulpoje. Šių ląstelių dirginimas lemia diferenciaciją i odontoklastus, kurie sukelia vidinę rezorbciją - pagrindinị tiesioginio padengimo nesėkmės pieniniuose dantyse požymį [12]. Todèl tiesioginio pulpos padengimo metodas pieniniams dantims netaikomas.

2. Netiesioginis pulpos padengimas. Taikant šį metodą, arčiausiai pulpos esantis dentino sluoksnis paliekamas ir padengiamas biosuderinama medžiaga, kuri skatina tretinio dentino gamybą, o dantis atstatomas hermetiška restauracija, kuri yra viena svarbiausių šio metodo sèkmès garantijų. [11] Taip išsaugomas pulpos gyvybingumas: sustabdomas éduonies progresas, sukeliama dentino sklerozè ir remineralizuojamas infekuotas dentinas [4]. Teigiama, kad esant giliam èduonies pažeidimui, dalinis èduonies pašalinimas yra geresnis pasirinkimas nei visiškas ėduonies išvalymas, nes taip sumažinama rizika atverti pulpą [14]. Netiesioginis pulpos padengimas rekomenduojamas pieniniams dantims, pažeistiems gilaus èduonies, tačiau neturintiems jokių pulpos dirginimo simptomų ar degeneracijos požymių [4]. Dažniausiai netiesioginiam pieninių dantų pulpos padengimui naudojamos medžiagos yra kalcio hidroksidas, MTA ir stiklo jonomerai. Iš esmès ši metodą būtų galima pavadinti pasyviu gydymo būdu, nes izoliavus èduonies paveiktą, bet ne infekuotą (ang. ,, affected " but not ,, infected ") pulpą nuo išorinio poveikio, paliekama galimybė jai pačiai regeneruoti [11]. Galima teigti, kad netiesioginis pieninių dantų pulpos padengimas yra vienas iš gilaus eduonies gydymo būdų, kai dantis yra besimptomis, kliniškai ir radiologiškai nestebima kitų patologinių pokyčių ir galima užtikrinti hermetišką galutinę danties restauraciją [4]. Tyrimais įrodyta, kad netiesioginis pieninių dantų padengimas yra žymiai sèkmingesnis metodas nei tiesioginis pieninių dantų padengimas ir tiek pat sèkmingas kaip pulpotomija $[4,14]$.

3. Pulpotomija. Tai pieninių dantų pulpos gydymo metodas, kai pašalinama vainikinè pulpos dalis ir ịvertinama likusi šakniné pulpa - ji turi būti gyva, be jokio pūlingo eksudato, blogo kvapo ar nekrozès požymių $[6,16]$. Likusi gyva šakninė pulpa kraujuoja, todèl kelioms minutèms yra padengiama vatele su tirpalu, kuris dezinfekuoja, mumifikuoja pulpos audinius ir stabdo kraujavimą [15]. Šis meto- 
das naudojamas pieninių dantų pulpos gydymui tuomet, kai nestebima jokių patologinių radiologinių pokyčių, t.y. esant sveikos pulpos atvėrimui dél gilaus éduonies, po traumos arba grịžtamo pulpito atvejais [6]. Dantis dažniausiai būna besimptomis arba stebima gilaus èduonies simptomatika - jautrumas saldžiam, karštam/šaltam maistui, gérimams, tačiau nèra savaiminio aštraus skausmo, taip pat nestebima jokių radiologinių ar klinikinių periodonto pažeidimo pokyčių $[15,16]$.

Yra pakankamai daug medžiagų, kurios gali būti naudojamos pulpotomijos metu: formokrezolio tirpalas, glutaraldehidas, paraformaldehidas, geležies sulfato tirpalas, cinko oksido eugenolis, kalcio hidroksidas, MTA, Ledermix ${ }^{\circledR}$ antibiotikų pasta, biokeraminès medžiagos, augimo faktoriai ir net iqvairios technologijos, tokios kaip lazeriai bei elektrokauteriai [17]. Pagrindinis ilgą laiką sèkmingai klinikinejje praktikoje naudojamas medikamentas šakninès pulpos padengimui yra formokrezolio tirpalas $[11,15]$. Jis mumifikuoja paviršinį šakninès pulpos sluoksnị ir taip pulpa lieka stabili iki danties iškritimo, uždegimas neplinta $[11,15]$. Tyrimais pastebèta, jog pulpotomija formokrezolio tirpalais gali paankstinti pieninių dantų šaknų rezorbciją (iškritimo laiką) [14]. Tačiau kol kas tai vienas iš efektyviausių klinikinèje praktikoje patikrintų medikamentų pieninių dantų pulpotomijai atlikti; kai kuriuose tyrimuose pulpotomija formokrezolio tirpalu laikoma auksiniu standartu, kontroline grupe, lyginant kitų medikamentų efektyvumą $[11,16]$. Šiuo metu atliekama daug ịvairių tyrimų formokrezolio tirpalo toksiškumui ịvertinti. Kai kuriose šalyse jo naudojimas uždraustas, tačiau pulpotomiją atlikti būtent formokrezolio tirpalu ir toliau mokoma JAV bei kitų šalių universitetuose [18]. Formokrezolio toksiškumui sumažinti buvo pradètas naudoti mažesnès $1 / 5$ koncentracijos tirpalas, o šio veiksmingumas patvirtintas klinikinëje praktikoje [11, 16]. Kad būtų galima sumažinti formokrezolio toksiškumą, buvo pasiūlyta naudoti glutaraldehidą. Jis turi tokias pačias pulpos audinius fiksuojančias savybes, tačiau yra mažiau antigeniškas, mažiau toksiškas bei ne taip giliai penetruojantis i audinius [11]. Geležies sulfatas yra alternatyvi formokrezolio tirpalui medžiaga. Pirmiausia jis buvo pradètas naudoti kaip hemostatinè medžiaga prieš padengiant šakninę pulpą kalcio hidroksidu, o vèliau ištirtas kaip atskiras medikamentas $[11,16]$. Jis nemumifikuoja paviršinio pulpos sluoksnio taip kaip formokrezolio tirpalas, bet amputacijos vietoje sukuria baltymini barjerą, panašų i kraujo krešuli. Tai kliniškai efektyvus pasirinkimas, ypač siekiant išvengti formokrezolio tirpalo naudojimo $[19,20]$. Kaip minèta, kalcio hidroksidas naudojamas jau nebekraujuojančios šakninès pulpos padengimui, tačiau pastebèta, kad jo efektyvumas žymiai mažesnis - pieniniuose dantyse dažnai prasideda vidinè rezorbcija [11]. Taigi kalcio hi- droksidas nėra pati geriausia alternatyva. MTA - dar viena medžiaga, kurią galima naudoti pulpotomijos metu. Ji sandariai užkloja šakninę pulpą, yra biosuderinama ir skatina pulpos audinių regeneraciją. Tyrimais ịrodyta, kad pulpotomijos su MTA sékmés procentas yra didžiausias lyginant su kalcio hidroksido, geležies sulfato ar formokrezolio pulpotomijų sékmès procentu [21], tačiau labai svarbus aspektas naudoti MTA pieninių dantų gydymui - tai sąlyginai brangi medžiaga [15]. Naujausios šiuolaikinès technologijos taip pat suteikia daugiau galimybių pulpos patologijų gydymui - pulpotomijai pradedami naudoti elektrokauteriai, lazeriai. Jų veikimas efektyvus, tačiau nepakankamai patvirtintas klinikiniais duomenimis, be to, jų naudojimas kol kas sunkiai pritaikomas vaikų odontologijoje [11]. Taip pat tai sąlyginai brangios technologijos, todèl indikuotinos tik siekiant bet kokiomis galimybemis išvengti formokrezolio naudojimo [22]. Galima daryti išvadą, kad formokrezolio tirpalas ir geležies sulfatas yra vienodai efektyvūs, lengvai naudojami ir lengvai prieinami medikamentai sékmingai pulpotomijai atlikti. Brangesnè, bet efektyvesnè alternatyva šioms medžiagoms - MTA.

Atliekant pulpotomiją, nuėmus vatelę su medikamentu nuo pieninio danties šaknų ịeigų kraujavimas turi būti sustojęs. Jei kraujavimas nestoja, vadinasi, uždegimas yra pasiekęs šakninę pulpą ir reikalingas radikalus jos gydymas pulpektomija. Jei kraujavimas sustoja, galima padengti kanalų įeigas ir pulpos kamerą atitinkama baze (dažniausiai cinko oksido eugenolio pasta) bei atstatyti danties vainiką hermetiška restauracija [6]. Nustatyta, kad vieno vizito pulpotomija, kai atlikus pulpotomiją dantis iškart atstatomas galutine hermetiška restauracija, yra sėkmingesnè nei dviejų vizitu pulpotomija $[14,16,17]$. Manoma, kad taip yra dèl laikinų užpildų pralaidumo [24].

Po pieninio danties gydymo pulpotomijos metodu ir atstačius danties vainiką, šaknine pulpa turi likti gyva, be jokių klinikinių simptomų (skausmo, jautrumo, tinimo) ar radiologinių pokyčių (išorinės ar vidinès šaknų rezorbcijos) [6].

Radikalūs pieninių dantų pulpos gydymo būdai. 1. Pulpektomija - pieninių dantų pulpos gydymo metodas, kai pašalinama visa vainikinè ir šakninè pulpa. Pulpektomija atliekama įvykus negrižtamiems pulpos pažeidimams arba nekrozei dèl éduonies ar traumos, taip pat tais atvejais, kai taikant pulpotomiją nesustoja kraujavimas iš šakninès pulpos [6]. Pulpektomiją galima taikyti, kai radiologiškai nestebima jokios arba yra minimali pieninio danties šaknų rezorbcija arba kiti minimalūs periodonto pažeidimai. Pulpektomijos metu pieninio danties šaknų kanalai mechaniškai valomi rankiniais instrumentais bei plaunami ir dezinfekuojami iriguojančiais tirpalais: $2 \%$ chlorheksidino bigliukonato tirpalu arba $1 \%$ natrio hipochlorito tirpalu $[6$, 
16] Labai svarbi yra šio chemomechaninio kanalų paruošimo rentgeno kontrole siekiant apsaugoti nuolatinių dantų užuomazgas [24]. Atlikus pulpektomiją, šaknų kanalai išsausinami ir užpildomi medžiaga, kuriai keliami du pagrindiniai reikalavimai: ji turi būti besirezorbuojanti kartu su pieninių dantų šaknimis bei turèti antibakterinių savybių [11]. Dažniausiai pieninių dantų kanalų užpildymui naudojama cinko oksido eugenolio, jodoformo arba kalcio hidroksido-jodoformo pasta [6, 16]. Ištirta, kad cinko oksido eugenolio pasta nèra pati geriausia pieninių dantų kanalų užpildymo medžiaga, nes ji ne visiškai rezorbuojasi kartu su pieninio danties šaknimis [11, 24]. Be to, sustingusi ji nebèra antibakteriškai veikianti. Todèl geresnis medikamentas kanalų plombavimui yra jodoforminè arba kalcio hidroksido-jodoformo pasta $[11,18]$. Taip pat nustatyta, kad šaknų kanalų užpildymas neprivalo būti iki pat šaknų viršūnių, svarbu kad būtų padengtas pulpos kameros dugnas - izoliuoti papildomi kanalai, susisiekiantys su bifurkacija. Danties vainikas turi būti atstatomas hermetiška ir patvaria restauracija $[6,24]$.

Atlikus pulpektomiją, būtinas radiologinis danties stebejjimas. Sèkmingos pulpektomijos atveju nèra patologinès šaknies rezorbcijos arba patologinių pokyčių bifurkacijoje, per 6 mènesius turi sugyti buvę periodonto pažeidimai radiologiškai tai stebima kaulo atsidejjimu ir formavimusi, taip pat per kelias savaites turi išnykti (jei buvo) klinikiniai simptomai $[6,11,24]$. Šis gydymo metodas turi nesutrukdyti pieninio danties šaknų rezorbcijos ir dantų kaitos.

2. Chirurginis pieninio danties šalinimas - radikalus pieninių dantų gydymo metodas, tačiau praktiškai vienintelis pasirinkimas esant tokioms pieninių dantų pulpos patologijoms kaip fistulè, patologinè šaknų, vidinè rezorbcija, periapikalinis židinys arba odontogeninis sepsis [26]. Taip pat tai yra nesėkmingo ankstesnio pieninio danties pulpos gydymo (pulpotomijos, pulpektomijos) išeitis. Pieninio danties ekstrakcija pasirenkama ir tuomet, kai iki pieninio danties iškritimo yra likę sąlyginai nedaug laiko (apie 1-1,5 metų), taip pat kai negalime užtikrinti hermetiškos restauracijos po pieninio danties pulpos gydymo, pavyzdžiui, yra likę per mažai danties kietụjų audinių [6]. Po krūminio pieninio danties šalinimo labai svarbus yra vietos užlaikymas, siekiant išvengti dantų lankų ir kitų ortodontinių deformacijų. Taip pat jei dantų lanke vienoje puseje jau yra prarastas pirmasis pieninis krūminis dantis, o priešingoje lanko pusèje sprendžiama dèl tokio paties danties endodontinio gydymo, tuomet rekomenduojama geriau rinktis ir šio danties šalinimą nei gydymą, kad būtų išvengta centrinès linijos pasislinkimo [16].

\section{Išvados}

1. Pieninių dantų ėduonis yra viena dažniausių vaikų lètinių ligų, jis diagnozuojamas keturis kartus dažniau nei ankstyvas vaikų nutukimas, penkis kartus dažniau nei astma bei dvidešimt kartu dažniau nei vaiku cukrinis diabetas.

2. Paliktas negydytas éduonis komplikuojasi pulpos pažeidimu (pulpitu), abscesu; dẻl pieninių dantų infekcijų paūmejjimo vaikus kartais tenka netgi hospitalizuoti. Mažiau išsivysčiusiose arba besivystančiose šalyse eduonis dažniau pažeidžia mažo ir labai mažo amžiaus vaikų dantis.

3. Pieninių dantų komplikuoto ėduonies gydymui galima taikyti ịvairius konservatyvius ir radikalius gydymo metodus, tačiau efektyviausia yra ėduonies pažeidimų profilaktika tiek nuolatiniame, tiek pieniniame sąkandyje. Tai yra svarbiausias uždavinys kiekvienam gydytojui odontologui, o gydant jau pažeistus pieninius dantis ne mažiau svarbu yra laiku teisingai nustatyti diagnozę ir pradèti taikyti konservatyvius pieninių dantų pulpos patologijų gydymo metodus, kad būtų galima išvengti ankstyvo pieninių dantų netekimo.

\section{Literatūra}

1. Petersen PE. Global policy for improvement of oral health in the 21 st century - implications to oral health research of World Health Assembly, World Health Organization. Community Dentistry and Oral Epidemiology 2009; 37:1-8.

http://dx.doi.org/10.1111/j.1600-0528.2008.00448.x

2. Razmienè J. Lietuvos ikimokyklines ịstaigas lankančių 4-6 metų amžiaus vaikų burnos higienos būklè, dantų pažeidžiamumas èduonimi, jo ryšys su šeimos socioekonomine padètimi. Internetinè prieiga: $\mathrm{http} / / / \mathrm{vddb}$.library.lt/fedora/get/LT-eLABa0001:E.02 2013 D_20140106_083857-01703/DS.005.0.02. ETD.

3. Slabšinskienė E., Milčiuvienė S., Narbutaitė J., Vasiliauskienė I., Andruškevičienė V., Bendoraitienè E.A., Saldūnaite K. Severe early childhood caries and behavioral risk factors among 3-year-old children in Lithuania, Medicina 2010; 46(2):135141.

4. Fuks AB, Guelmann M, Kupietzky A. Current developments in pulp therapy for primary teeth. Endodontic Topics 2010; 23:50-72.

http://dx.doi.org/10.1111/etp.12003

5. Ng FK, Messer LB. Mineral trioxide aggregate as a pulpotomy medicament: an evidence-based assessment. European Archives of Paediatric Dentistry 2008; 9(2):58-73.

http://dx.doi.org/10.1007/BF03262612

6. American Academy of Pediatric Dentistry (AAPD). Guidelines on pulp therapy for primary and immature permanent teeth. Reference Manual 33(6):244-248.

7. Lynch RJM. The primary and mixed dentition, post-eruptive enamel maturation and dental caries: a review. International 
Dental Journal 2013; 63:3-13.

http://dx.doi.org/10.1111/idj.12076

8. Lenzi TL, Guglielmi Cde A, Arana-Chavez VE, Raggio DP. Tubule density and diameter in coronal dentin from primary and permanent human teeth. Microscopy and Microanalysis 2013; 19(6):1445-1449.

http://dx.doi.org/10.1017/S1431927613012725

9. Aminabadi NA, Farahani RM, Gajan EB. Study of root canal accessibility in human primary molars. Journal of Oral Science 2008; 50(1):69-74.

http://dx.doi.org/10.2334/josnusd.50.69

10. Cleghorn BM, Boorberg NB, Christie WH. Primary human teeth and their root canal systems. Endodontic Topics 2010; 23:6-33.

http://dx.doi.org/10.1111/etp.12000

11. Ranly D, Garcia-Godoy F. Current and potential pulp therapies for primary and young permanent teeth. Journal of Dentistry 2000; 28(3):153-161.

http://dx.doi.org/10.1016/S0300-5712(99)00065-2

12. Kennedy DB, Kapala JT. The dental pulp: biological considerations of protection and treatment. Textbook of Pediatric Dentistry $1985 ; 2: 492-522$.

13. Ricketts D, Kidd E, Innes N, Clarkson J. Complete or ultraconservative removal of decayed tissue in unfilled teeth. Australian Dental Journal 2007; 52:252-253.

http://dx.doi.org/10.1111/j.1834-7819.2007.tb00497.x

14. Farooq NS, Coll JA, Kuwabara A, Shelton P. Success rates of formocresol pulpotomy and indirect pulp therapy in the treatment of deep dentinal caries in primary teeth. Pediatr Dent 2000; 22(4):278-286.

15. Balaprasanna-Kumar C. Pulpotomy in primary teeth - a review. JIADS. 2011; 2(2):29-31.

16. Rodd HD, Waterhouse PJ, Fuks AB, Fayle SA, Moffat MA. Pulp therapy for primary molars. International Journal of Pediatric Dentistry 2006; 15-23.

17. Markovic D, Zivojinovic V, Vucetic M. Evaluation of three pulpotomy medicaments in primary teeth. European Journal of Paediatric Dentistry. 2005; 6(3):133-138.

18. Primosch RE, Glomb TA, Jerrell RG. Primary tooth pulp therapy as taught in predoctoral pediatric dental programs in the United States. Pediatric Dentistry. 1997; 19(2):118-122.

19. Fuks AB, Holan G, Davis JM, Eidelman E. Ferric sulfate versus dilute formocresol in pulpotomized primary molars: long-term follow up. Pediatric Dentistry 1997; 19(5):327-330.

20. Fei AL, Udin RD, Johnson R. A clinical study of ferric sulfate as a pulpotomy agent in primary teeth. Pediatric Dentistry 1991; 13(6):327-332.

21. Stringhini Junior E, Vitcel ME, Oliveira LB. Evidence of pulpotomy in primary teeth comparing MTA, calcium hydroxide, ferric sulphate, and electrosurgery with formocresol. European Archives of Paediatric Dentistry 2015; 16(4):303-312. http://dx.doi.org/10.1007/s40368-015-0174-z

22. Elliott RD, Roberts MW, Burkes J, Phillips C. Evaluation of the carbon dioxide laser on vital human primary pulp tissue. Pediatric Dentistry 1999; 21(6):327-331.

23. Guelmann M, Fair J, Turner C, Courts FJ. The success of emergency pulpotomies in primary molars. Pediatric Dentistry 2002; $24: 3$.

24. Coll JA, Josell S, Casper JS. Evaluation of a one-appointment formocresol pulpectomy technique for primary molars. Journal of Pediatric Dentistry 1985; 7(2):123-129.

25. Baginska J, Stokowska W. Pulpal involvement-roots-sepsis index: a new method for describing the clinical consequences of untreated dental caries. Medical Principles and Practice 2013; 22:555-560. http://dx.doi.org/10.1159/000354193

26. American Academy of Pediatric Dentistry (AAPD). Policy on early childhood caries (ECC): classifications, consequences, and preventive strategies. Reference Manual 2014;37(6):50-51.

27. Leal SC, Bronkhorst EM, Fan M, Frencken JE. Untreated cavitated dentine lesions: impact on children's quality of life. Caries Research 2012; 46(2):102-106.

http://dx.doi.org/10.1159/000336387

28. Li Y, Wang W. Predicting caries in permanent teeth from caries in primary teeth: an eight-year Cohort study. Journal of Dental Research 2002; 81(8):561-566. http://dx.doi.org/10.1177/154405910208100812

\section{PULP THERAPY METHODS FOR PRIMARY TEETH} V. Siurblytė , E. A. Bendoraitienė, E. Slabšinskienė, R. Grigalauskienė, I. Vasiliauskienè, J. Razmienė

Key words: primary teeth anatomy, pulpotomy, pulpectomy, formocresol, pulp therapy.

Summary

Early childhood caries is one of the most common child chronic diseases in the world, especially in countries with poor socioeconomic status and in both developed and developing worlds. Odontogenic infections in untreated teeth are very frequent and make a negative impact in child's life: it's harmful for overall child's health, causes poor nutrition, low body weight index, stress and anxiety, dental pain or even odontogenic sepsis; furthermore child may develop low self-esteem, have problems attending school. It is highly relevant to review current pulp therapy methods for primary teeth, because in countries with high early childhood caries prevalence the lesions are usually left untreated. This article summarizes the materials and methods of pulp therapy in primary teeth.

Correspondence to: vitalija.siurblyte@gmail.com

Gauta 2016-05-16 